Jurnal Keperawatan Silampari

Volume 4, Nomor 2, Juni 2021

e-ISSN: 2581-1975

p-ISSN: 2597-7482

DOI: https://doi.org/10.31539/jks.v4i2.1632

\title{
PANDEMI COVID-19 TERHADAP KONDISI PSIKOLOGIS PETUGAS KESEHATAN
}

\author{
Lilik Wijayati $^{1}$, Djazuly Chalidyanto ${ }^{2}$, Budhi Setianto ${ }^{3}$ \\ Universitas Airlangga ${ }^{1,2}$ \\ Universitas Nahdlatul Ulama ${ }^{3}$ \\ lilik.wijayati-2018@fkm.unair.ac.id ${ }^{1}$
}

\begin{abstract}
ABSTRAK
Penelitian ini bertujuan untuk mengkaji pengaruh pandemic covid-19 pada kondisi psikologis petugas kesehatan. Desain penelitian yang digunakan adalah pencarian sistematis pada beberapa basis data termasuk DOAJ, Sage, Proquest, Medline, Google Scholar, Science Direct mulai Februari hingga Juni 2020. Dari beberapa artikel terdapat bukti praklinis yang rasional mengenai risiko kesehatan mental atau psikologis sebagai akibat dari Covid-19. Perasaan cemas, stres, depresi atau ketakutan bahkan kepanikan akibat Covid-19 ini memicu meningkatnya risiko kesehatan psikologis atau mental yang dihadapi petugas kesehatan sehingga terapi atau kegiatan kelompok atau individu perlu dilakukan. Simpulan, terdapat bukti pra-klinis yang rasional mengenai risiko kesehatan mental atau psikologis akibat korona. Kecemasan, stres atau depresi atau ketakutan bahkan kepanikan akibat kasus korona ini memicu meningkatnya risiko kesehatan psikologis atau mental yang dihadapi oleh petugas kesehatan sehingga terapi atau kegiatan kelompok atau individu perlu diterapkan.
\end{abstract}

Kata Kunci: Covid-19, Pandemi, Pelayanan Kesehatan, Petugas Kesehatan, Psikologis

\begin{abstract}
This study aims to examine the effect of the COVID-19 pandemic on the psychological condition of health workers. The research design used is a systematic search on several databases, including DOAJ, Sage, Proquest, Medline, Google Scholar, Science Direct, from February to June 2020. There is Rational pre-clinical evidence regarding mental or psychological health risks from several articles as a result of Covid-19. Feelings of anxiety, stress, depression or fear, and even panic due to Covid-19 trigger increased psychological or mental health risks faced by health workers so that therapy or group or individual activities need to be carried out. In conclusion, there is reasonable pre-clinical evidence regarding the mental or psychological health risks due to corona. Anxiety, stress or depression or fear, and even panic due to this corona case trigger increased psychological or mental health risks faced by health workers so that therapy or group or individual activities need to be applied.
\end{abstract}

Keywords: Covid-19, Pandemic, Health Services, Health Officers, Psychological 


\section{PENDAHULUAN}

Virus korona yang terbaru secara resmi disebut 'SARSCoV-2' oleh Komite Internasional Taksonomi Virus, sedangkan penyakit yang disebabkan oleh virus ini disebut 'COVID-19 (Ridlo, 2020). Sejak penyebaran penyakit epidemi ini, pemerintah China segera merilis pengumuman kepada publik mengenai pencegahan dan pengobatan penyakit menular serius, yang diperlukan untuk menentukan langkah-langkah yang efektif dan langsung untuk mencegah penularan penyakit ini (Ripp et al., 2020). Kesehatan mental merupakan hal yang sangat penting untuk kesejahteraan individu secara keseluruhan dan tentunya sangat penting pula untuk kehidupan yang produktif dan efisien (Goyena \& Fallis, 2019). Di tempat kerja, masalah kesehatan mental ditemukan memiliki kaitan dengan banyak pengaruh negatif, termasuk penurunan efisiensi, hilangnya produktivitas, kecacatan dan ketidakhadiran (Saha \& Khan, 2021).

Wabah Corona Virus Disease 2019 (COVID-19) yang muncul pada Desember 2019 di Wuhan, dengan cepat menyebar ke luar Tiongkok, sehingga World Health Organization (WHO) mengumumkan Darurat pada Public Health Emergency of International Concern (PHEIC), menyebabkan Tekanan Psikologis pada tenaga Kesehatan yang menangani Pasien COVID-19, tujuan dari penelitian ini untuk mengetahui Gangguan Psikologis pada Tenaga Kesehatan selama Masa pandemi COVID-19 (Pinggian et al., 2021). Petugas kesehatan menghadapi tekanan psikologis terkait COVID-19 yang belum pernah terjadi sebelumnya di seluruh domain profesi dan pribadi. Sebuah studi cross-sectional pada petugas kesehatan di China menemukan bahwa lebih dari 50\% dari mereka mengalami depresi dan lebih dari $70 \%$ mengalami kesusahan selama pandemi COVID-19 (Zhang et al., 2020). Di NYC, kematian akibat bunuh diri dilakukan oleh petugas garda depan yang merawat pasien COVID-19. Sedangkan, data kuantitatif mengenai jenis dan tingkat stres terkait COVID-19 di antara petugas kesehatan Amerika Serikat (AS) masih kurang (Yang et al., 2020).

Sebuah penelitian yang dilakukan pada sukarelawan kesehatan di sebuah rumah sakit di Jawa Tengah menemukan gambaran psikologis pada sukarelawan COVID-19 dimana 68 orang $(95.83 \%)$ mengalami kecemasan ringan, 69 orang $(95.83 \%)$ mengalami depresi ringan dan 69 orang (95.83\%) mengalami stress ringan (Goyena \& Fallis, 2019).

Penelitian ini sudah pernah dilakukan oleh peneliti sebelumnya, namun penelitian ini berfokus pada literature review beberapa artikel tentang kondisi psikologis petugas kesehatan pada masa pandemi Covid-19.

\section{METODE PENELITIAN}

Penelitian ini dilakukan melalui tinjauan pustaka pada beberapa database besar seperti Proquest, Sciencedirect, Doaj, Sagepub, Medline, dan Google Scholar menggunakan kata kunci pandemi Covid-19, psikologis, tenaga kesehatan, pelayanan kesehatan. Batasan waktu yang diberikan adalah Februari - Juni 2020. Dari 1.537 artikel, terdapat 10 artikel yang memenuhi kriteria inklusi. Artikel tersebut termasuk mengenai 1) desain penelitian RCT, 2) berbagai pengaruh Pandemi Covid-19 terhadap psikologis, 3) sampel petugas kesehatan di rumah sakit, dan 4) parameter yang menilai intensitas pengobatan untuk menurunkan risiko gangguan psikologis.

Dari 10 literatur yang didapat, terdapat berbagai pengaruh Pandemi Covid-19 terhadap psikologis, termasuk kecemasan, stres dan depresi. Instrumen yang digunakan untuk mengukur pencapaian tujuan keselamatan pasien antara lain kuesioner, lembar checklist observasi, dan lembar wawancara. Jenis instrumen yang sering digunakan adalah DASS (Depression Anxiety Stress Scale). 
HASIL PENELITIAN

Tabel.1

Literature Review

\begin{tabular}{|c|c|c|c|c|}
\hline No & $\begin{array}{l}\text { Pengarang, Judul, } \\
\text { Jenis Literatur }\end{array}$ & Tahun & Tujuan & Hasil Temuan \\
\hline 1. & $\begin{array}{l}\text { Jianbo et al., } \\
\text { Factors Associated } \\
\text { With Mental Health } \\
\text { Outcomes Among } \\
\text { Health Care } \\
\text { Workers Exposed to } \\
\text { Coronavirus } \\
\text { Disease 2019, } \\
\text { Survei Cross- } \\
\text { Sectional }\end{array}$ & 2020 & $\begin{array}{l}\text { Untuk Mengetahui } \\
\text { Faktor-Faktor yang } \\
\text { Berhubungan } \\
\text { Dengan Hasil } \\
\text { Kesehatan Mental Di } \\
\text { Antara Tenaga } \\
\text { Kesehatan yang } \\
\text { Terkena Penyakit } \\
\text { Coronavirus } 2019\end{array}$ & $\begin{array}{l}\text { Sebagian besar } \\
\text { peserta melaporkan } \\
\text { gejala depresi ( } 634 \\
[50,4 \%]), \text { kecemasan } \\
(560[44,6 \%]) \text {, } \\
\text { insomnia }(427 \\
[34,0 \%]) \text {, dan } \\
\text { kesusahan (899 } \\
[71,5 \%])\end{array}$ \\
\hline 2. & $\begin{array}{l}\text { Ripp et al., } \\
\text { Attending to the } \\
\text { Emotional Well- } \\
\text { Being of the Health } \\
\text { Care Workforce in a } \\
\text { New York City } \\
\text { Health System } \\
\text { During the COVID- } \\
19\end{array}$ & 2020 & $\begin{array}{l}\text { Untuk mengetahui } \\
\text { Kesejahteraan } \\
\text { Emosional Tenaga } \\
\text { Kesehatan di Kota } \\
\text { New York Sistem } \\
\text { Kesehatan Selama } \\
\text { Pandemi COVID-19 }\end{array}$ & $\begin{array}{l}\text { Melalui upaya ini, } \\
\text { gugus tugas } \\
\text { mengidentifikasi } 3 \\
\text { bidang prioritas yang } \\
\text { diyakini sebagai } \\
\text { pusat dalam } \\
\text { mempromosikan dan } \\
\text { menjaga } \\
\text { kesejahteraan seluruh } \\
\text { tenaga kerja MSHS } \\
\text { selama pandemi: (1) } \\
\text { memenuhi } \\
\text { kebutuhan dasar } \\
\text { tenaga kerja selama } \\
\text { krisis (2) } \\
\text { meningkatkan } \\
\text { komunikasi untuk } \\
\text { membantu } \\
\text { penyampaian pesan } \\
\text { terkini, andal, dan } \\
\text { meyakinkan yang } \\
\text { menginformasikan } \\
\text { tenaga kerja, dan (3) } \\
\text { mengembangkan } \\
\text { serangkaian pilihan } \\
\text { dukungan } \\
\text { psikososial dan } \\
\text { kesehatan mental } \\
\text { yang mudah diakses. }\end{array}$ \\
\hline 3. & $\begin{array}{l}\text { Li et al., } \\
\text { Psychological status } \\
\text { of medical } \\
\text { workforce during } \\
\text { the COVID-19 } \\
\text { pandemic, } \\
\text { A cross-sectional } \\
\text { study }\end{array}$ & 2020 & $\begin{array}{l}\text { Untuk Mengetahui } \\
\text { Status psikologis } \\
\text { tenaga medis selama } \\
\text { pandemi COVID-19 }\end{array}$ & $\begin{array}{l}\text { Proporsi kelompok } \\
\text { staf medis pada } \\
\text { ketakutan sedang dan } \\
\text { berat lebih tinggi } \\
\text { dibandingkan pada } \\
\text { kelompok staf } \\
\text { administrasi (70,6\% } \\
\text { VS 58,4\%). (1) } \\
\text { analisis lebih lanjut } \\
\text { tentang faktor-faktor } \\
\text { yang memudahkan }\end{array}$ \\
\hline
\end{tabular}




\begin{tabular}{|c|c|c|c|c|}
\hline & & & & $\begin{array}{l}\text { mereka merasa } \\
\text { khawatir, tertekan, } \\
\text { atau frustrasi, (2) } \\
\text { Seperti yang } \\
\text { diharapkan, beberapa } \\
\text { faktor berkontribusi } \\
\text { pada perluasan } \\
\text { tekanan psikologis } \\
\text { termasuk bekerja di } \\
\text { bangsal isolasi. }\end{array}$ \\
\hline 4. & $\begin{array}{l}\text { Juan et al., } \\
\text { Covid-19 } \\
\text { Psychological } \\
\text { Impact In } 3109 \\
\text { Healthcare Workers } \\
\text { In Spain, } \\
\text { The Psimcov Group }\end{array}$ & 2020 & $\begin{array}{l}\text { Untuk Mengetahui } \\
\text { Dampak Psikologis } \\
\text { Covid-19 Pada } 3109 \\
\text { Tenaga Kesehatan } \\
\text { Di Spanyol, }\end{array}$ & $\begin{array}{l}\text { Dari 1671 dokter } \\
\text { yang menyelesaikan } \\
\text { survei, dampak } \\
\text { psikososial tertinggi } \\
\text { dirasakan dalam } \\
\text { pengobatan } \\
\text { Pernapasan, mean } \\
\text { (sd) PSAS adalah } \\
\text { 48,3 (13,6) dan } \\
\text { Geriatri } 47,6 \text { (16,4). } \\
\text { Tingkat marabahaya } \\
\text { yang lebih tinggi } \\
\text { ditemukan di daerah } \\
\text { dengan insiden } \\
\text { COVID-19 tertinggi } \\
\text { (>245,5 kasus per } \\
\text { 100.000 orang), } \\
\text { PSAS 46,8 (15,2); } \\
\text { P<0,001. Responden } \\
\text { stres paling sedikit } \\
\text { adalah PSAS pekerja } \\
\text { asimtomatik, } 41,3 \\
(15,4) \text {; P }<0,001, \\
\text { serta mereka yang } \\
\text { berusia di atas } 60 \\
\text { tahun, PSAS, } \\
\text { 37.6(16); P<0,001. } \\
\text { Pekerja yang } \\
\text { membutuhkan terapi } \\
\text { psikologis dan tidak } \\
\text { mendapatkan PSAS } \\
\text { lebih stres 52,5 } \\
(13,6) \text { dibandingkan } \\
\text { pekerja yang tidak } \\
\text { membutuhkan PSAS } \\
\text { 39,7(13,9) P<0,001. }\end{array}$ \\
\hline 5. & $\begin{array}{l}\text { Soeyon et al., } \\
\text { The Mental Health } \\
\text { Burden of the } \\
\text { COVID-19, } \\
\text { Pandemic on } \\
\text { Physical Therapists }\end{array}$ & 2020 & $\begin{array}{l}\text { Untuk Mengetahui } \\
\text { Beban Kesehatan } \\
\text { Mental dari COVID- } \\
19\end{array}$ & $\begin{array}{l}21(32,3 \%) \text { dan } 12 \\
(18,5 \%) \text { ahli terapi } \\
\text { fisik dilaporkan } \\
\text { memiliki gejala } \\
\text { kecemasan dan } \\
\text { depresi, masing- } \\
\text { masing. } \\
\text { Dengan demikian, } \\
\text { fisioterapis yang } \\
\text { tinggal dengan bayi } \\
\text { atau anak berusia_6 } \\
\text { tahun dan mereka }\end{array}$ \\
\hline
\end{tabular}




\begin{tabular}{|c|c|c|c|c|}
\hline & & & & $\begin{array}{l}\text { yang berusia 30-an } \\
\text { dan 50-an } \\
\text { memerlukan } \\
\text { perhatian khusus. }\end{array}$ \\
\hline 6. & $\begin{array}{l}\text { Buseli et al., } \\
\text { Psychological Care } \\
\text { of HealthWorkers } \\
\text { during the COVID- } \\
19 \text { Outbreak in } \\
\text { Italy: Preliminary } \\
\text { Report of an } \\
\text { Occupational } \\
\text { Health Department } \\
\text { (AOUP) } \\
\text { Responsible for } \\
\text { Monitoring Hospital } \\
\text { Staff Condition, } \\
\text { Kelompok } \\
\text { intervensi } \\
\text { PsicoCovid19 }\end{array}$ & 2020 & $\begin{array}{l}\text { Untuk Mengetahui } \\
\text { Perawatan } \\
\text { Psikologis Tenaga } \\
\text { Kesehatan selama } \\
\text { Wabah COVID-19 } \\
\text { di Italia }\end{array}$ & $\begin{array}{l}\text { Di antara total } \\
\text { sampel, 60\% } \\
\text { menerima renovasi } \\
\text { dari program terapi } \\
\text { sebelumnya. } \\
\text { Sedangkan 7\% } \\
\text { beralih dari terapi } \\
\text { psikiatri ke terapi } \\
\text { kombinasi dengan } \\
\text { tambahan terapi } \\
\text { psikologis. Hasilnya } \\
\text { menunjukkan bahwa } \\
\text { mereka yang } \\
\text { meminta bantuan } \\
\text { terutama adalah } \\
\text { perawat wanita yang } \\
\text { sudah mengalami } \\
\text { kerentanan kesehatan } \\
\text { mental. Diperlukan } \\
\text { pendekatan klinis } \\
\text { yang lebih spesifik } \\
\text { gender. }\end{array}$ \\
\hline 7. & $\begin{array}{l}\text { Yuhong et al., } \\
\text { Psychological } \\
\text { impact of the } \\
\text { coronavirus disease } \\
2019 \text { (COVID-19) } \\
\text { outbreak on } \\
\text { healthcare workers } \\
\text { in China }\end{array}$ & 2020 & $\begin{array}{l}\text { Untuk Mengetahui } \\
\text { Dampak psikologis } \\
\text { dari wabah penyakit } \\
\text { coronavirus } 2019 \\
\text { (COVID-19) pada } \\
\text { petugas kesehatan di } \\
\text { Tiongkok }\end{array}$ & $\begin{array}{l}\text { Kekhawatiran utama } \\
\text { petugas kesehatan } \\
\text { adalah: infeksi rekan } \\
\text { kerja, }(72,5 \%) \text {, } \\
\text { infeksi anggota } \\
\text { keluarga }(63,9 \%), \\
\text { tindakan } \\
\text { perlindungan } \\
(52,3 \%) \text { dan } \\
\text { kekerasan medis } \\
(48,5 \%) \text {. Dan } 39,1 \% \\
\text { petugas kesehatan } \\
\text { mengalami tekanan } \\
\text { psikologis, }\end{array}$ \\
\hline
\end{tabular}

Berdasarkan tabel 1 hasil sistematic review menunjukan bahwa dari beberapa artikel terdapat bukti pra-klinis yang rasional mengenai risiko kesehatan mental atau psikologis sebagai akibat dari Covid-19. Perasaan cemas, stres, depresi atau ketakutan bahkan kepanikan akibat Covid-19 ini memicu meningkatnya risiko kesehatan psikologis atau mental yang dihadapi petugas kesehatan sehingga terapi atau kegiatan kelompok atau individu perlu dilakukan.

\section{PEMBAHASAN}

\section{Kecemasan}

Rasa khawatir/takut/ cemas yang terlalu berlebihan secara menerus yang dirasakan dalam keseharian akan menyebabkan jantung berdenyut kencang, nafas pendek tersengal, perasaan lelah dan mudah berkeringat. Perasaan ini akan menjadi suatu hal yang normal walaupun terkadang akan menggangu dalam kehidupan keseharian. 
Sebuah proyek penelitian yang dilakukan oleh Jianbo lai, et al (2020) menunjukkan pengaruh Covid-19 terhadap gangguan psikologis. Sebagian besar peserta melaporkan gejala depresi sebanyak $634(50,4 \%)$, kecemasan sebanyak $560(44,6 \%)$, insomnia sebanyak 427 (34,0\%), dan kesusahan sebanyak 899 (71,5\%). Beberapa penelitian menunjukkan bahwa proporsi kelompok staf medis pada ketakutan sedang dan berat lebih tinggi daripada kelompok staf administrasi (70,6\% vs 58,4\%) (Lu, 2020; Romero et al., 2020). Hasil penelitian menunjukkan fakta nyata bahwa Covid-19 menyebabkan gangguan kecemasan pada petugas kesehatan.

\section{Stres}

Sebuah proyek penelitian menunjukkan pengaruh Covid-19 terhadap gangguan stres. Di antara 1.671 dokter yang terlibat dalam survei, efek psikososial tertinggi dirasakan pada pengobatan saluran pernapasan. Tingkat kesusahan yang lebih tinggi ditemukan di daerah dengan kejadian COVID-19 tertinggi (> 245,5 kasus per 100.000 orang). Responden yangmengalami stres paling rendah adalah pekerja tanpa gejala serta mereka yang berusia di atas 45 tahun. Hasil penelitian menunjukkan fakta nyata bahwa Covid-19 mempengaruhi gangguan stres pada petugas kesehatan (Yang et al., 2020).

\section{Depresi}

Sebuah penelitian yang dilakukan menunjukkan pengaruh Covid-19 terhadap gangguan depresi. Dibandingkan dengan petugas kesehatan nonmedis $(\mathrm{n}=1.255)$, petugas kesehatan medis $(\mathrm{n}=927)$ memiliki prevalensi insomnia $(38,4$ vs $30,5 \%, \mathrm{p}<0,01)$, kecemasan $(13,0$ vs $8,5 \%$, p <0,01), depresi (12,2 vs. 9,5\%; $\mathrm{p}<0,04)$, somatisasi (1,6 vs. $0,4 \% ; \mathrm{p}<0,01)$, dan gejala obsesif-kompulsif yang lebih tinggi. Hasil penelitian menunjukkan fakta nyata bahwa Covid-19 mempengaruhi gangguan depresi pada petugas kesehatan (Lu, 2020).

\section{SIMPULAN}

Terdapat bukti pra-klinis yang rasional mengenai risiko kesehatan mental atau psikologis akibat korona. Kecemasan, stres atau depresi atau ketakutan bahkan kepanikan akibat kasus korona ini memicu meningkatnya risiko kesehatan psikologis atau mental yang dihadapi oleh petugas kesehatan sehingga terapi atau kegiatan kelompok atau individu perlu diterapkan. Dalam proses pencapaian kesadaran kesehatan jiwa (psikologis) diharapkan adanya kerjasama yang baik dari seluruh elemen rumah sakit sehingga proses tersebut dapat berjalan secara maksimal dan berdampak positif pada peningkatan kualitas pelayanan kesehatan.

\section{SARAN}

Area prioritas untuk mempromosikan dan menjaga kesejahteraan tenaga kerja selama pandemi Covid-19: (1) Kebutuhan dasar: makanan, rumah, transportasi, keamanan pribadi dan pengasuhan anak, (2) Komunikasi: sistem dan area tempat kerja lokal yang luas, (3) Dukungan psikososial dan kesehatan mental: ketahanan dan perawatan diri, dukungan wawancara kelompok, dukungan singkat individu, dukungan kesehatan mental jangka panjang untuk individu, dan manajemen krisis. 


\section{DAFTAR PUSTAKA}

Goyena, R., \& Fallis, A. (2019). Pengaruh Work life Balance terhadap Kepuasan Kerja. Journal of Chemical Information and Modeling, 53(9), 1689-1699

Lu, W. (2020). Since January 2020 Elsevier has Created a COVID-19 Resource Centre with Free Information in English and Mandarin on the novel coronavirus COVID19 . The COVID-19 Resource Centre is Hosted on Elsevier Connect, the Company' s Public News and Information. Psychiatry Resaerch, January

Pinggian, B., Opod, H., \& David, L. (2021). Dampak Psikologis Tenaga Kesehatan selama Pandemi COVID-19. Jurnal Biomedik: Jbm, 13(2), 144-151. https://doi.org/10.35790/jbm.13.2.2021.31806

Ridlo, I. A. (2020). Pandemi COVID-19 dan Tantangan Kebijakan Kesehatan Mental di Indonesia. INSAN Jurnal Psikologi dan Kesehatan Mental, 5(2), 162. https://doi.org/10.20473/jpkm.v5i22020.162-171

Ripp, J., Peccoralo, L., \& Charney, D. (2020). Attending to the Emotional Well-Being of the Health Care Workforce in a New York City Health System During the COVID-19 Pandemic. Academic Medicine, 95(8), 1136-1139. https://doi.org/10.1097/ACM.0000000000003414

Romero, C. S., Catalá, J., Delgado, C., Ferrer, C., Errando, C., Iftimi, A., Benito, A., De Andres, J., \& Otero, M. (2020). COVID-19 Psychological Impact in 3109 Healthcare workers in Spain: The Psimcov Group. Psychological Medicine, C. https://doi.org/10.1017/S0033291720001671

Saha, S. R., \& Khan, D. M. M. H. (2021). Prevalence and Determinants of Mental Distress during COVID-19 Outbreak in Bangladesh: Evidence from an Online Survey. Journal of Applied Science, Engineering, Technology, and Education, 3(1), 90-103. https://doi.org/10.35877/454ri.asci150

Yang, S., Kwak, S. G., Ko, E. J., \& Chang, M. C. (2020). The Mental Health Burden of the Covid-19 Pandemic on Physical Therapists. International Journal of Environmental Research and Public Health, 17(10). https://doi.org/10.3390/ijerph17103723

Zhang, W. R., Wang, K., Yin, L., Zhao, W. F., Xue, Q., Peng, M., Min, B. Q., Tian, Q., Leng, H. X., Du, J. L., Chang, H., Yang, Y., Li, W., Shangguan, F. F., Yan, T. Y., Dong, H. Q., Han, Y., Wang, Y. P., Cosci, F., \& Wang, H. X. (2020). Mental Health and Psychosocial Problems of Medical Health Workers during the COVID-19 Epidemic in China. Psychotherapy and Psychosomatics, 89(4), 242250. https://doi.org/10.1159/000507639 